\title{
TEN YEARS OF NATURE TRAILING
}

THE NATURE TRAILS AND TRAILSIDE MUSEUMS

AT BEAR MOUNTAIN, N. Y.

(In Two Parts)

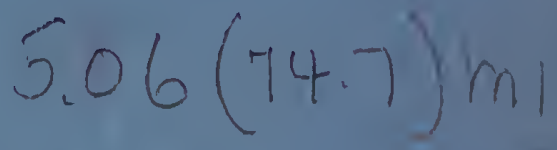

\section{WILLIAM H. CARR}

SCHOOL SERVICE SERIES, NUMBER ELEVEN 1937

Department of Education

THE AMERICAN MUSEUM OF NATURAL HISTORY

CENTRAL PARK WEST AT 79TH STREET

NEW YORK, N. Y. 


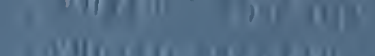

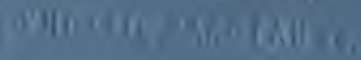




\section{TEN YEARS OF NATURE TRAILING}

\section{Part One}

A report of the development and operation of the Bear Mountain Nature Trails and Trailside Museums from April first, 1927, to July first, 1935, under the joint auspices of the Commissioners of the Palisades Interstate Park and the American Museum of Natural History, and financed and operated by the American Museum of Natural History.

\section{Part Two}

Operation with support of the State of New York and the sponsorship of the American Museum of Natural History and the Commissioners of the Palisades Interstate Park.

WILLIAM H. CARR

Director, Bear Mountain Nature Trails and Trailside Museums

Park Naturalist, Palisades Interstate Park

Assistant Curator (Outdoor Education)

Department of Education

The American II useum of Natural History

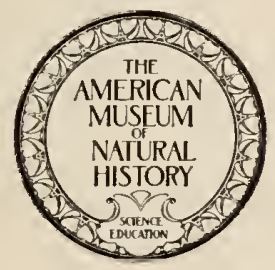

SCHOOL SERVICE SERIES, NUMBER ELEVEN 1937

Published by

The Department of Education 


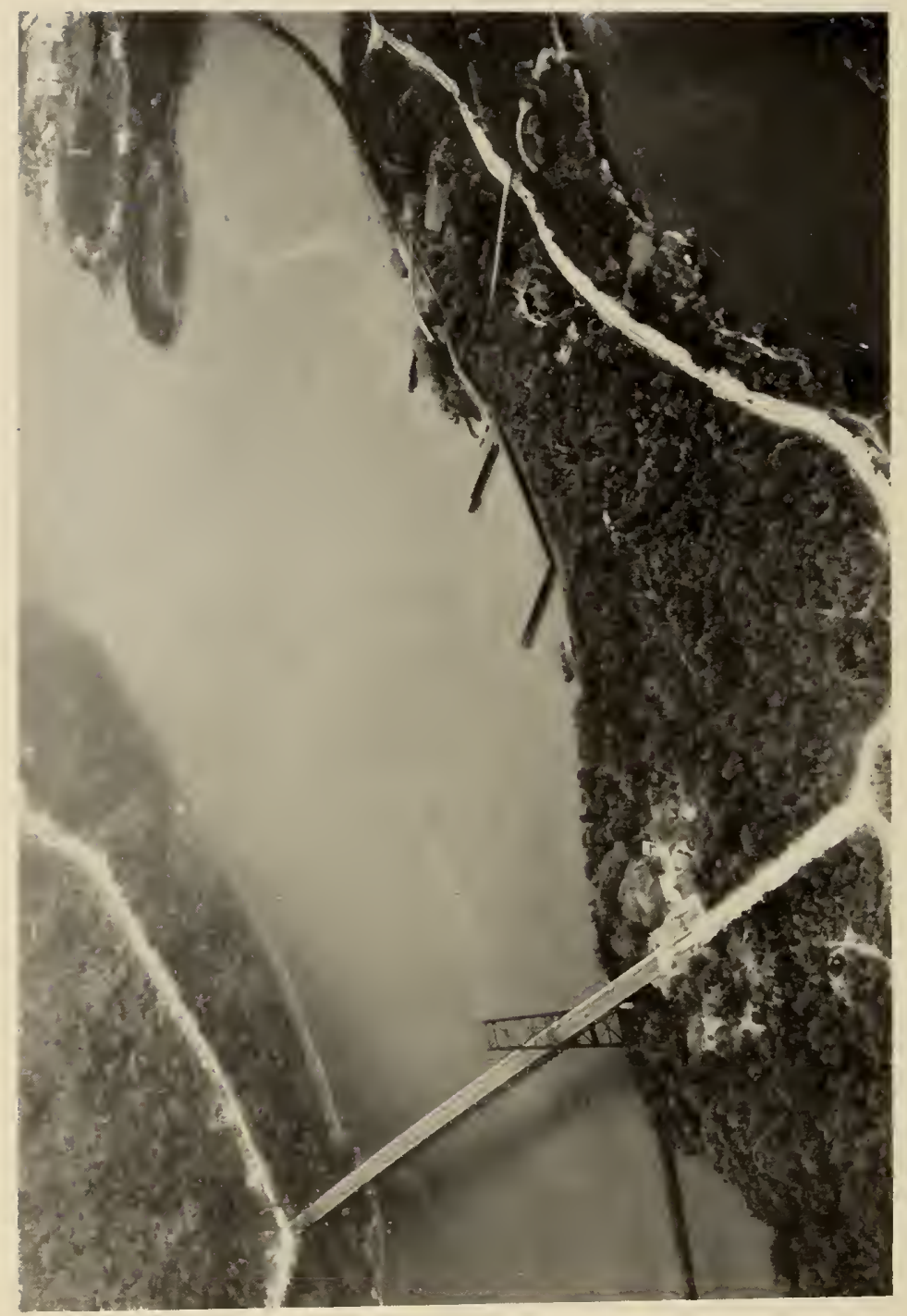

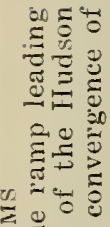

है क

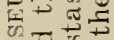

焉 3

데 0 월

证

$\Xi \overline{3}=$

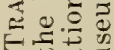

-

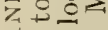

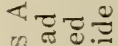

$=28:=$

ए

Eี

芯三总

일

乙远

的。

E.

50.2

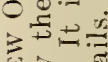

至需

य

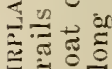
틀

空

๘क

工 $\approx$

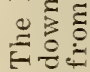




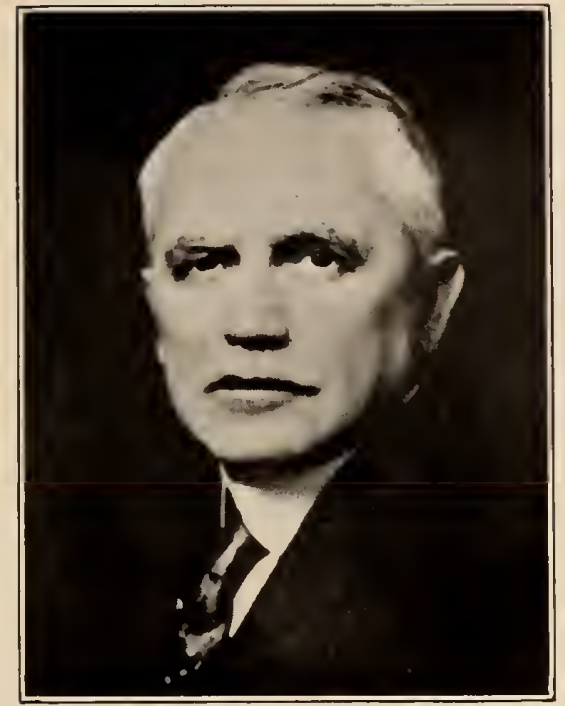

George Herbert Sherwood

March 28, 1876 - March 18, 1937

Adrocate and Supporter of Outdoor Nature Education

\section{FOREWORD}

The Bear Mountain Nature Trails and Trailside Museums, occupying some fifty acres of woodland, are located on the Hudson River in Palisades Interstate Park of New York. This project was initiated by the American Association of Museums through the vision of Dr. Hermon C. Bumpus, Chairman of the Association's Committee on Outdoor Education, and under a grant from the Laura Spelman Rockefeller Memorial. The Commissioners of the Palisades Interstate Park, through Major William A. Welch, Chief Engineer and General Manager of the Park, enthusiastically cooperated in the undertaking. Major Welch not only has directed the construction of the Trailside Museum buildings and other physical equipment but has continuously encouraged all phases of the work. When the first Trailside Museum building was completed, the Commissioners of the Park invited the American Museum of Natural History to undertake the supervision and operation of the trails and museums, and with the hearty support of President Henry Fairfield Osborn the American Museum accepted this invitation.

For the first eight years the project was maintained and operated jointly by the Commissioners of Palisades Interstate Park and the American Museum of Natural History. The financing of this experiment in outdoor education was made possible through the generous contributions of Mr. Felix M. Warburg, a 
broad-visioned educator and a trustee of the American Museum. At the close of this period the American Museum had demonstrated conclusively the value of such education, and, since hundreds of thousands of citizens of the State were enjoying and profiting by these activities, felt that the time had come when the State should take over the financing of the project as one of the features of Palisades Interstate Park.

The State of New York responded to this suggestion, and since July 1, 1935, the Nature Trails and Trailside Museums have been carried on with an appropriation from the State. At the request of the Commissioners of the Park, the American Museum of Natural History has continued to supervise their operation.

From the very beginning, William $\mathrm{H}$. Carr has been the resident director and official representative of the Museum. It is largely due to his energy, resourcefulness, devotion to duty, and infectious enthusiasm that such noteworthy results have been attained in this pioneer undertaking. He has gathered around him a corps of skilled associates who carry out his ideas with splendid team work.

At the end of the first decade it is well to review what has been accomplished, consider the problems that have been solved, and present briefly the policies that are guiding us.

During the past two years the Park Commissioners have built several new Museum buildings and landscaped the northerly portion of the Trailside area. While these changes may seem to overshadow the original Nature Trail, they are, after all, only supplementary to the trail work. One feature of our policy that has been adhered to faithfully is that no specimen,-zoological, botanical, mineralogical or historical,-is to be permanently a part of the Nature Trail or the Trailside Museums unless it is indigenous to the Bear Mountain area or directly associated with it.

It is our hope that this resumé of the Nature Trails and Trailside Museums at Bear Mountain will stimulate others to take up such activities and thereby spread the gospel of outdoor nature education.

George H. Sherwood, Curator Department of Education American Museum of Natural History Central Park West at 79th Street New York, N. Y.

January 25, 1937. 


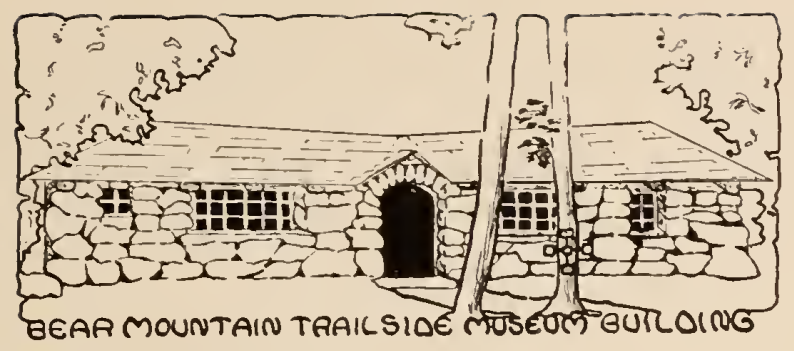

\section{Part One

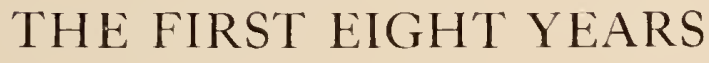 \\ 1927 - 1935}

9. Trailside Museums, of many people, and of many ideas. Above all, it is a story of action.

The scene is laid upon the forested heights of the Bear Mountain plateau, beyond the granite cliffs bordering the west The bank of the Hudson River, forty-five miles north of New Place York City. Deep valleys, grassy fields, and tall trees of of woodland where our work has gone forward. Shaded pools are scattered throughout the area and Hessian Brook flows through an extensive, moist thicket on its way to the great river below.

A fierce military engagement between defending American forces and invading British troops took place upon this historic ground on October 6, 1777 . Wandering stone ramparts of old Fort Clinton remain to mark the battle site. Fragments of Indian pottery have been unearthed within a few hundred yards of the fort, indicating an earlier and perhaps more peaceful occupancy.

From the American Revolutionary period until early in the twentieth century the region was given over to farming and to The the gradual but certain ruination of the forest and the Park destruction of a once abundant animal population. In
1907 proposals were made to erect a huge penitentiary not far from the site of our present activities. If this plan had been carried forward, the magnificent scenic approach to 
the Hudson Highlands would have been spoiled forever. Fortunately a group of public-spirited citizens banded together and defeated the prison scheme. As a result, the Bear Mountain Harriman section of the Palisades Interstate Park came into being in 1909. Protection, preservation and promulgation took the place of promotion, desecration, and destruction. The Park soon became one of the foremost recreation centers in the United States and millions of persons have enjoyed rest and relaxation there. Thousands upon thousands of campers have spent weeks and months within this wild life sanctuary.

In 1920 the first organized movement was set afoot to acquaint campers and general visitors alike with the natural his-

\section{Educational}

Backgrounds

tory features and values of the region to the end that the park would be intelligently enjoyed and actively appreciated. It was believed that all efforts to further the cause of conservation of natural resources should be based upon an honest attempt at public education.

A field museum was maintained in a log pavilion on the shore of Kanawauke Lake in the center of the 43,000 -acre park territory. Mr. B. T. Benjamin Hyde, known to countless campers as "Uncle Bennie," made this initial museum and pioneer outdoor educational program possible. The results obtained were successful beyond expectation. A long-felt need had been definitely met and decisively answered.

During the next several years the Park Commission, with "Uncle Bennie's" aid, erected small museums in the five camping centers. These excellent institutions, supported and staffed by the Commissioners, have since been operated during July and August of each year. They are known as Regional Museums.

In 1925 Dr. Frank E. Lutz, Curator of Entomology at the American Museum, established an original Nature Trail on the western border of the Park, in connection with a "Station for the Study of Insects."* This Nature Trail was maintained for three summers. "Uncle Bennie's" museum was closed permanently in 1927, after seven seasons of highly useful endeavor in conjunction with a large number of Boy Scout camps then located at Kanawauke Lake. The American Museum had aided in all branches of this work from the first.

* See Bibliography Page 35 . 


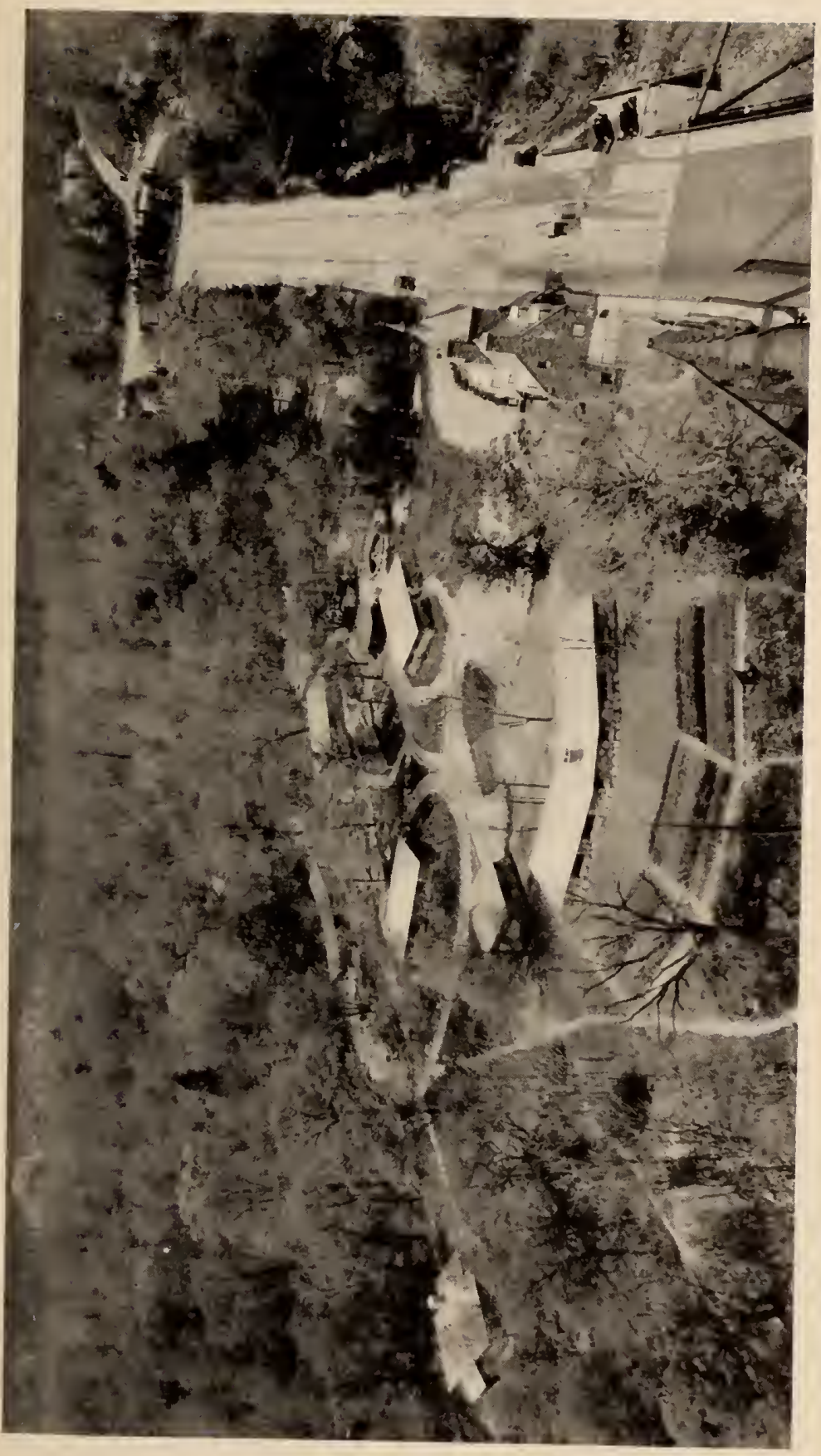

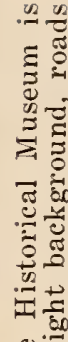

$\stackrel{\square}{=}$

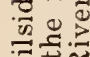

도

Е. ตีย 월 $z^{E-}=$

క웡

乙 政 을 ๘ फ 될 中, o :

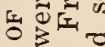
०

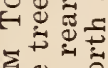

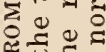

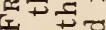
4 ह 40. 资 뵈 䑻 ⿷匚 붕제 象证。 สิธ $\approx 00$ 5 5 जु

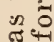

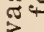
3

ำ కృ s का E. 
In 1927, at the instigation of the American Association of Museums, an educational unit known as the Trailside Museum was erected by the Park Commission at Bear Mountain in the eastern section of the Park, where the great majority of visitors enter. Funds for the building were provided by the Laura Spelman Rockefeller Memorial. The American Museum of Natural History maintained this field museum and contributed to the development of a Nature Trail. The Park Commission, in addition to making the site available, also gave freely of materials and supplies. The growth and operation of this outof-door institution is the subject of the present account.

The writer will ever be grateful for the privilege of having been associated with the educational movement in the Palisades Interstate Park from the time of its inception in 1920. The work accomplished here has spread, not only throughout America, but also around the world. More than two million persons have visited the Bear Mountain Nature Trails and Trailside Museums alone. In many respects we feel that opportunities for added public service are limitless.

1. Nature Trails are informational footpaths leading through the woods and fields. Nature provides all the illustrations. Let-

Trailside Definitions tered guides, attached unobtrusively to objects in place, tell the story. Nature Trails have become both highways and vehicles of learning. The visual presentation of accurate knowledge, by means of informal outof-door signs, constitutes an outstanding method whereby the broad field of natural history may become a truly open book.

One of the first labels placed upon our Bear Mountain Nature Trails read:

\section{"SIGNS ALONG THE TRAIL"}

"How many of us are able to read, unaided, the 'signs' of

Nature? Let the guiding labels take the place of a naturalist friend who has an interesting story to tell you as you follow the trail."

2. Trailside Museums are "covered trails." In a very important sense they are not museums at all. We refer here, as elsewhere throughout this booklet, only to the Bear Mountain Trailside Museums. Our Trailside units are designed as focal points and concentration centers for the two and one-half miles of Nature Trails. Living animals and other exhibits within the small buildings are placed under shelter because they could 
not be well protected elsewhere along the trails.

The same type of information is disseminated indoors as is given out of doors. There is additional reference material in the buildings, and also added facilities for the study of objects, animate and inanimate, first observed by the visitor upon the trails. Formal museum exhibits here give way to simple presentations of local natural history where the tactile as well as the visual sense comes into play. In effect, Trailside $\mathrm{Mu}$ seums are out-of-door nature laboratories.

Work upon the Nature Trails commenced in April of 1927. We first made a careful survey of the aforementioned fiftyEarly seven acres, determining the location and varieties of Trail plants and rocks. Then, commencing at the southDays eastern end of the property, we planned the first trail. The entrance was placed at the head of a ramp that serves to bring thousands of visitors from the Hudson River steamboat piers below to the Bear Mountain Inn grounds above. We tapped the center of this human flow at the point where

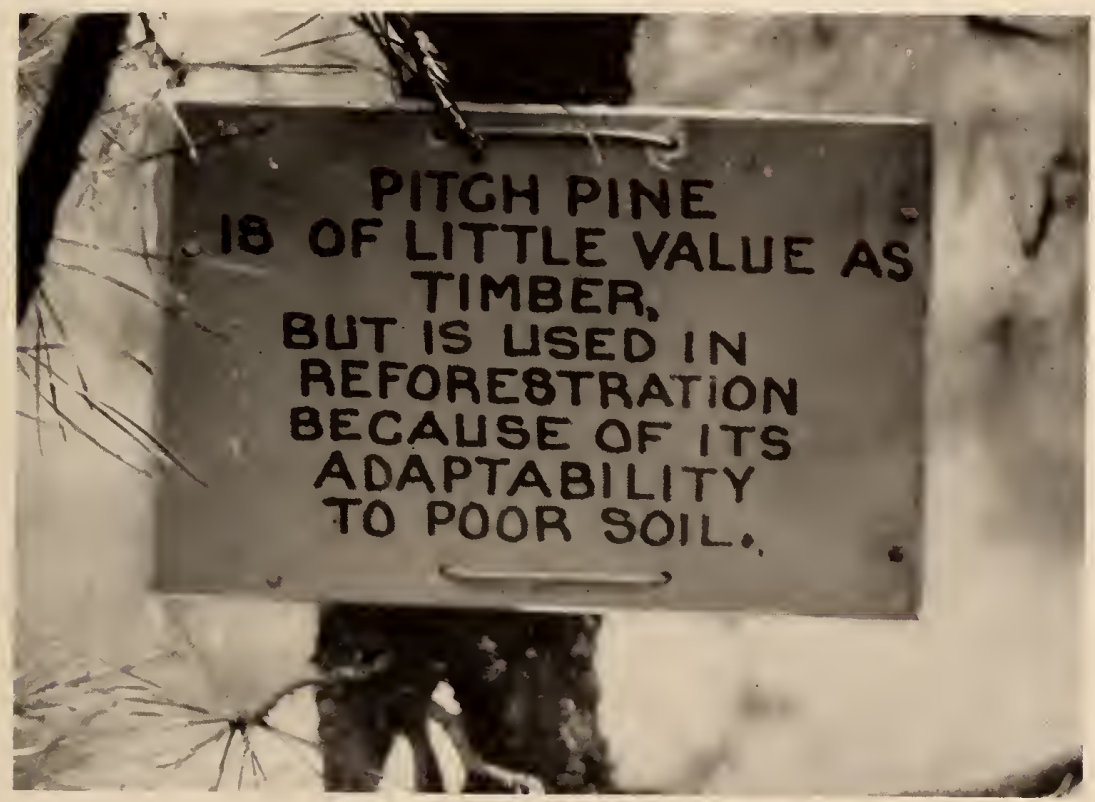

Labels Along The Trail

These inconspicuous signs acquaint the nature lover with natural objects in place, and help to interpret them. One reads, remembers, and enjoys. 


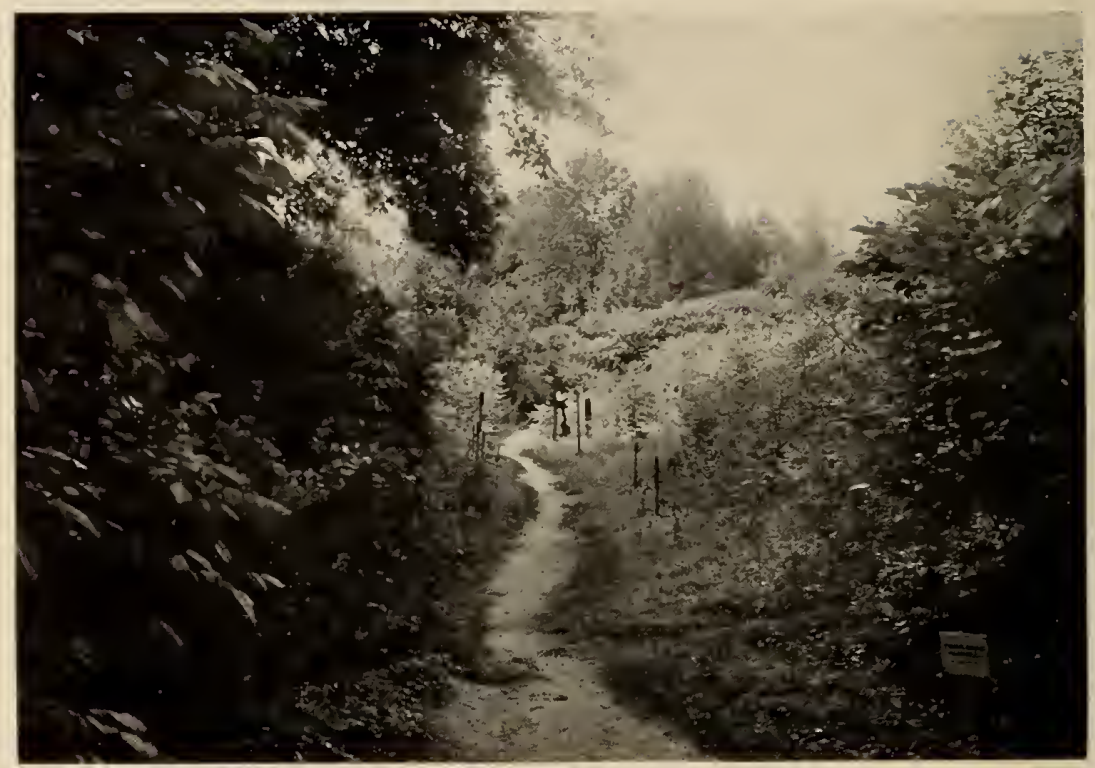

The Field Trail

(Photograph by M. Peter Keene)

people pause to rest after a steep climb. Forty thousand persons sometimes use the ramp in a single day. A rustic cedar arbor was erected at this spot to lead the eye to our entrance sign.

The trail runs northward to the Trailside Museum. It follows, not the path of least resistance, but the way that leads to the most interesting natural features, including trees, shrubs, smaller plants, and numerous rock formations. From the museum the footpath continues on to the west gate toll-house of the Bear Mountain Bridge, half a mile from the starting point. This path has always been known as the "main trail."

From the outset, we avoided any plan involving the destruction of trees or the displacement of rocks to smooth the way. We followed the more laborious process of laying out a welldefined trail that skirted ravines, circled trees, climbed hills, and followed the slopes of sheer rock walls. At a later date many additional side trails were marked and the main trail was extended. Eventually there were separate pathways for local history, botany and geology, all intercepting and all interrelated, in regard to types of information made available. Our 
return trail follows Hessian Brook, and the nearby Acorn Trail is designed as an experimental path to enable visitors to test their knowledge.

The trails were gradually labeled during the first five seasons of six months each year. We proceeded largely by the trial and error system. Hundreds of labels were made and discarded. At one time we reached the stage of completing sixty metal signs each day. Every sign was framed with chestnut strips and was hand-lettered. Some twenty words were included in each label.

The foundation for the Trailside Museum was laid in May, 1927, and the building was ready for use in September of the Trailside Museum Beginnings same year. While awaiting the completion of this work we made full use of an abandoned shanty, a relic of construction days of the Bear Mountain Bridge. Forty-eight tons of scrap iron lay about where bridge engineers had left it. The spot was literally an iron shambles. Four years went by before we were able to pay

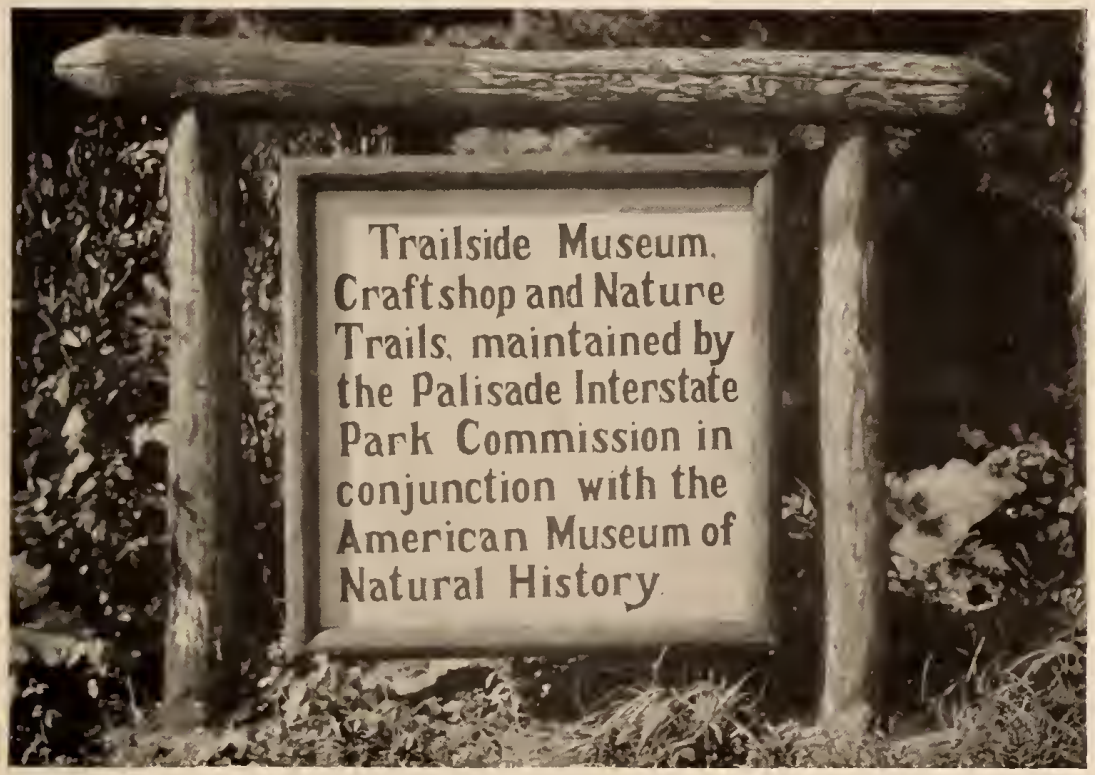

Sign On State Road

These large signs were placed near the Bear Mountain Bridge entrance. 


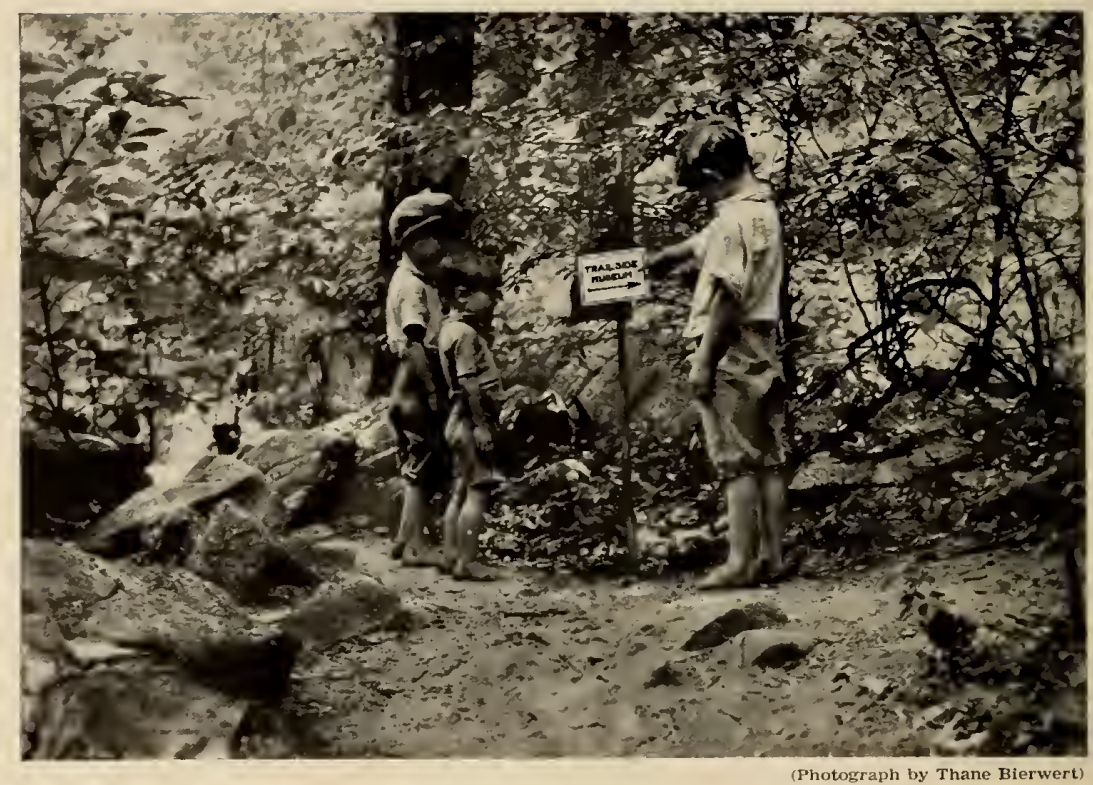

The ARrow PoInts The Way

a junk dealer to wield his acetylene torch and then carry off the material.

The shanty was our home during several months of the first season. A partition was erected in the east end of the shed to separate our living quarters from the museum and workshop built in the west section. The demands made upon us at this time were heavy indeed. From the very beginning, many waking hours have been spent with visitors who come to seek advice and to ask questions.

Several years passed before we fully realized that the original Trailside building was too small for our needs. In the meantime the Park Commission had erected a fine slab cabin for living quarters. The shanty was entirely devoted to museum and workshop purposes and another similar shed nearby had been transformed to serve as a combination zoo and laboratory. Running water and electricity came as twin blessings. Equipment needed for the museum and the trails was built by us in the workshop. We used lumber and other supplies discarded from the American Museum and the Park Commission 
carpenter shops. Many volunteers aided in construction activities which filled happy, busy hours of the days and nights.

Animal cages made at this time ultimately found their way into the various Regional Museums, for we were only too glad to assist the camps and to provide equipment whenever possible. These were days of back-breaking toil and constant uncertainty as to whether our project was to be continued from one year to the next. In fact, we have never suffered from the "dangers of security!"

In the spring of 1932 the Park Commission, with funds provided by the New York State Temporary Emergency Relief AdNew ministration, commenced a museum building proTrailside Units gram. During the following three years, four new museum structures, one stone cabin and a fine garage were added to our Trailside equipment, bringing our total number of buildings to eight. Separate buildings were erected for botany, geology, history, and nature crafts. These buildings, styled after our original Trailside Museum, were placed near the Bear Mountain Bridge toll-house. They did not encroach upon our Nature Trail area in any way.

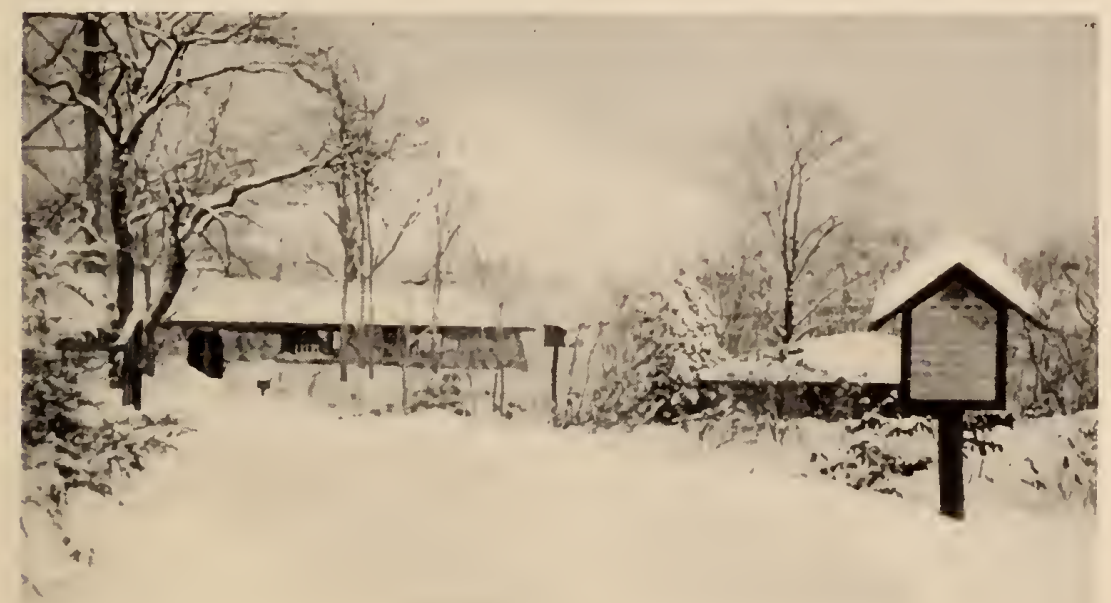

WINTER SCENE

(Photograph by Richard J. Koke)

The buildings are especially picturesque when covered with snow. During the winter 1935-1936 the snow was quite deep, and the Museum and Park cooperated in feeding and caring for stricken wild life. 


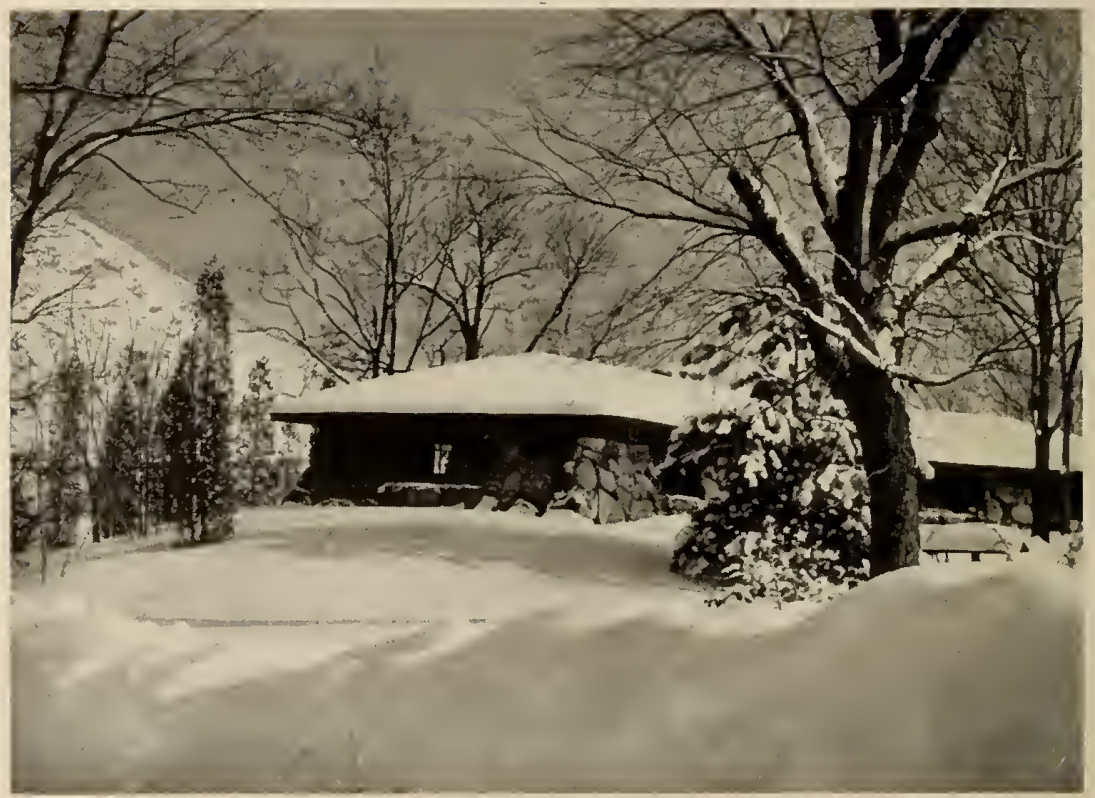

HEAVY SNOWS

Winter activities were not at all curtailed during stormy weather. Many of our visitors were skiers, hikers and campers, coming to Bear Mountain for the popular winter sports.

Perhaps the most auspicious event, in connection with the completion of our new museums, was the dedication of a memorial to Stephen Tyng Mather, on our Geology Trail. This memorial to the first Director of the National Park Service consisted of a bronze plaque, placed upon a huge glacial boulder. The Secretary of the Interior, Harold L. Ickes, delivered the principal address, and Mrs. Franklin Delano Roosevelt, wife of the President, unveiled the tablet on May 27, 1933. There had never been a formal dedication of any sort upon our Trailside area before this date.

In planning for effective use of all trails and museums, we have had many ideals in mind. Our objectives have been threeConstant fold. We have encouraged people in the open to obAims serve with understanding, to enjoy periods of leisure and recreation intelligently, and to apply their newly gained knowledge to the advancement of both conserva- 
tional and cultural education in their own communities. It is our intent to build a constructive teaching program wherein all of our facilities will be available to all of the people. The identification of plants, animals, and rocks and minerals is but a part of the work. Our aims are much broader than this.

Ecology and taxonomy here go hand in hand. Our Trailside Museum was devoted to the "Story of Interdependence" for the entire season of 1932.* The subject of life histories vies in importance with means and methods of identification. We teach physiography in addition to geology and mineralogy, and archaeology as well as history. The subject of "woods etiquette" is not forgotten in our curriculum either-for human behavior is part of the story! It has always been our endeavor to build educational foregrounds and backgrounds in natural history simultaneously; to stress knowing as well as naming.

\section{*See "Trailside Interdependence," Am. Mus. pub. 1933.}

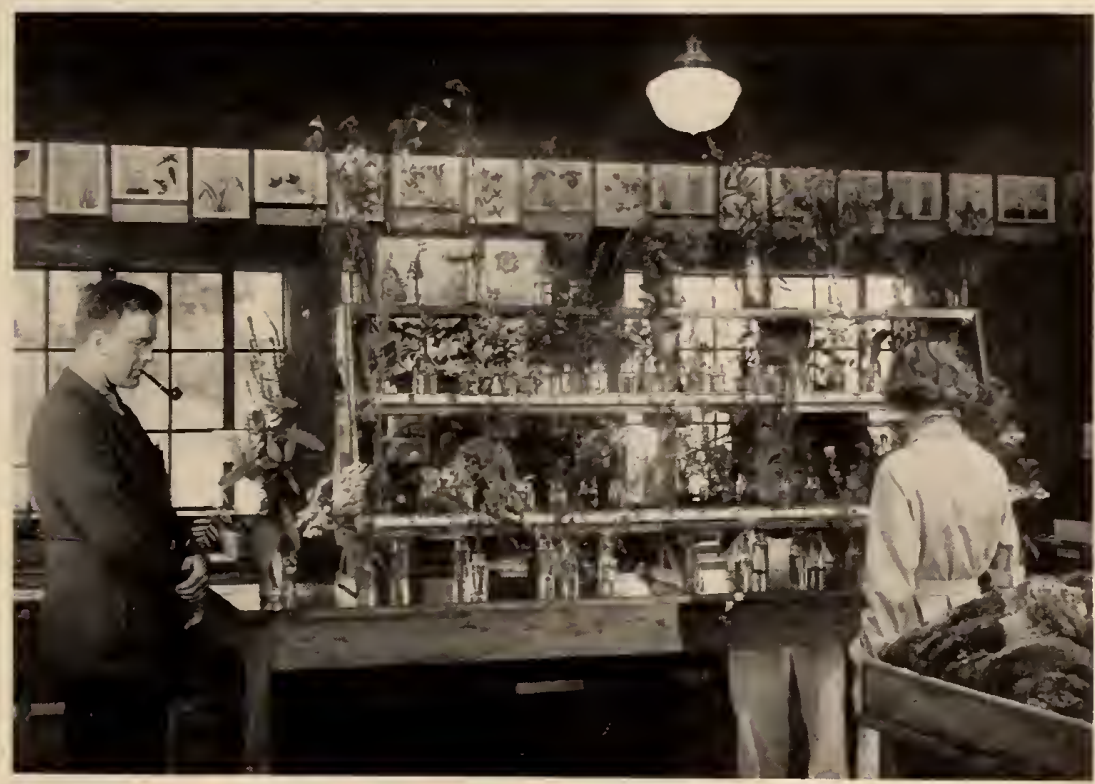

Trailside Botany Museum

(Phowograph by Thane Bierwert)

Over the length and breadth of the Palisades Interstate Park, nature has scattered a profusion of wild flowers. Here a colorful array is presented as a means of learning names and appearance at the same time. 


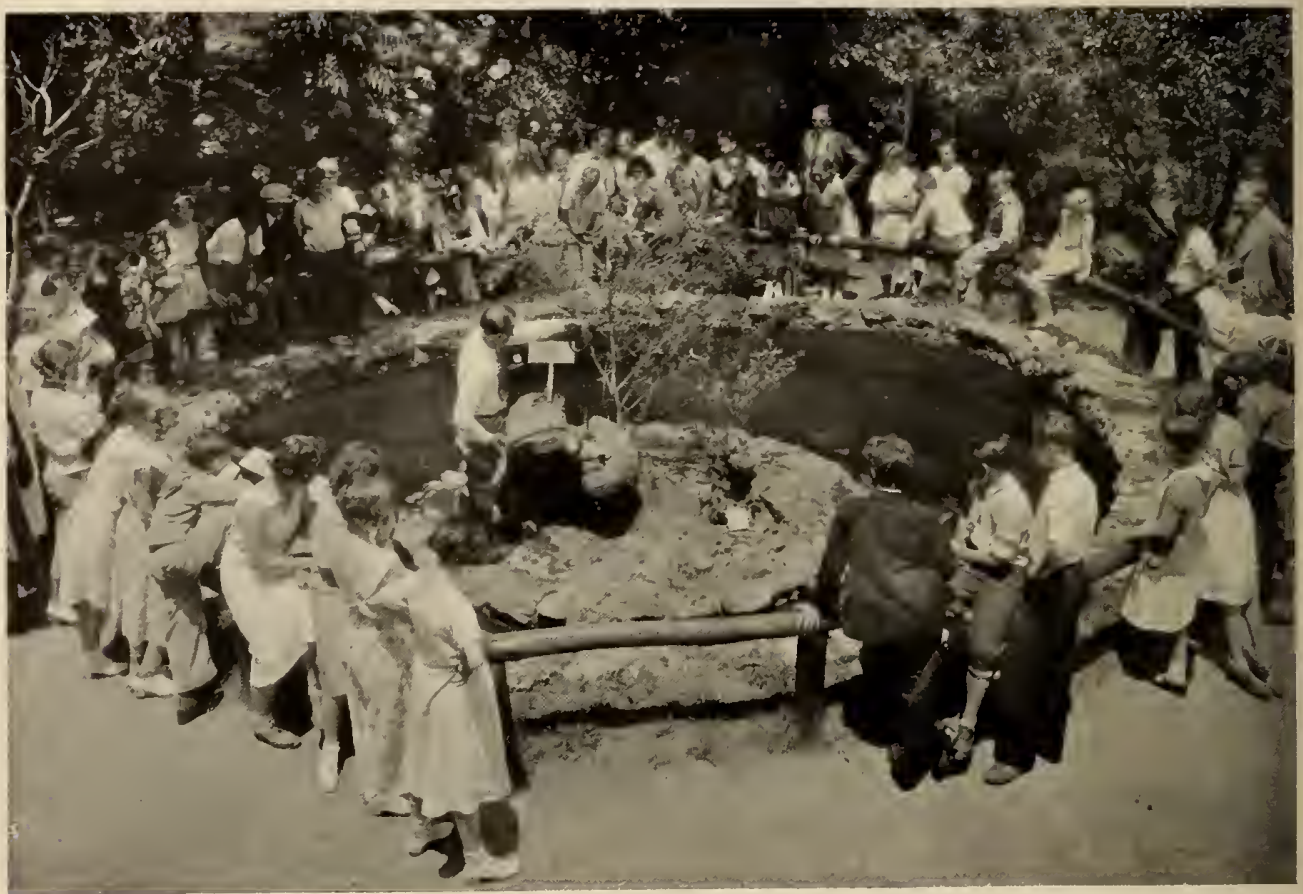

The SNAKE PIT

Local snakes displayed upon an island surrounded by a moat.

Our teaching methods include the following principal types of approach :

a. VISUAL: including trail and museum labels, exhibits and library. (60\% effective)

Public b. TACTILE: including all exhibits, indoors and out, that Approach may be touched without moving, manipulated in place, or lifted and handled. (25\% effective)

c. PERSONAL CONTACT : including lectures, guiding trips and conversations with museum visitors, answering questions, etc.

(15\% effective)

Percentages given above refer to relative numbers of interested visitors who avail themselves of the three means of subject approach offered. We are constantly trying to increase the percentage of personal contacts with general visitors, for we believe this to be the best form of service rendered. A practice has been made of carefully analyzing types of "natural history conversations" to the extent of building a filing system containing several thousand cards to record typical questions, opinions, and general reactions of visitors. The information 
thus gathered serves as a decidedly practical guide in preparing new labels and exhibits.

We have always believed that too much time and money has been wasted in preparing exhibits first and consulting the public, for whom the exhibits were intended, last. This cart-before-the-horse procedure leads, only too often, to extensive and costly alterations. It is possible to present practically any phase of natural history in a popular, thoroughly accurate manner. It has been our experience in Trailside work that public likes and dislikes should always be considered if the builder desires to create displays that will be appreciated by the great majority of visitors. Our primary interest in this regard relates to labels and labeling.

As the principal function of Nature Trails is to acquaint visitors with natural objects in situ by means of explanatory Labels labels, we find that both the "physical and mental" composition of the signs is of great importance. Much has been said and written about ways and means of wording labels. Actual, every-day experience has taught us more than any printed material we could discover. We have published several pamphlets dealing with our work along these lines.*

Each label, indoors and out, invariably contains information in addition to names. In describing plants, animals and rocks we classify our labels as follows :

1. Hints as to identification and classification (Taxonomy).

2. Relationships and interrelationships of plants and animals to their environment (Ecology).

3. Commercial and domestic values (Industrial uses).

4. Inspirational (Ideas).

5. Educational values (Hints to teachers, etc.).

6. Fact and fiction (General information).

7. Growth and development (Life history).

8. Distribution (Geographical).

The wording and composition of each label is simple and the approach direct. The scope of this "ten year" report will not permit a full discussion of ways and means of labeling. Therefore we once more refer to previously issued pamphlets.*

*“Signs Along The Trail," 1927, "Blazing Nature's Trail," 1929, etc., pub. by Am. Mus. Nat. Hist. 


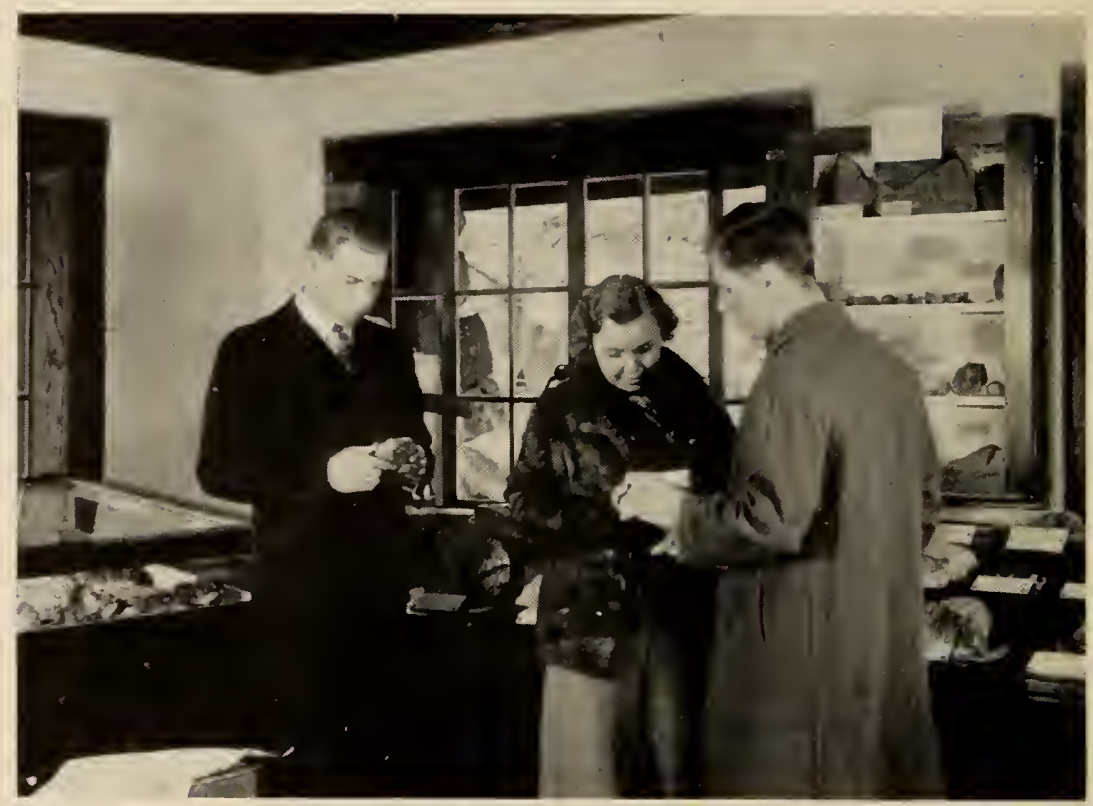

A Corner of The Geology Museum

Specimens of local rocks and minerals are placed in easy reach on shelves and may be picked up and handled by interested visitors. The Park is rich in geological lore.

The various Trailside Museum units, like the Nature Trails, are considered as the means to an end, and not the end in itself. Trailside

Museum

Methods

Once more labels function to interpret exhibits. The Trailside Zoology Museum, by means of charts, diagrams, drawings and photographs, serves to amplify and crystallize stories related out of doors. There are living check lists of local fish, amphibians, and reptiles. Many living insects, crustaceans, and other animal types are also on display.

The Trailside Botanical Museum is operated in a similar fashion, also employing charts, labels, and many hundreds of living specimens to illustrate the flora of the Hudson Highlands. Seasonal exhibits of the common wild flowers and "weeds" have proved of much value in concentrating information given along the trails, where, of necessity, the specimens 
are often few and far between. A large space is devoted to plant ecological demonstrations and kindred subjects.

The Trailside Geology Museum, also maintained on an "open house" basis, contains an extensive reference collection of local rocks and minerals. Most of the display specimens are arranged to permit free handling and close examination. There are but four small, glass-topped cases to protect especially "desirable" material. Elsewhere rocks and minerals alike are presented on open shelves and table tops. Various testing devices enable visitors to identify specimens through personal effort and initiative. Many opportunities are present for the use of hand, eye, and brain.

In each museum, and in the Trailside Crafthouse, staff mem-

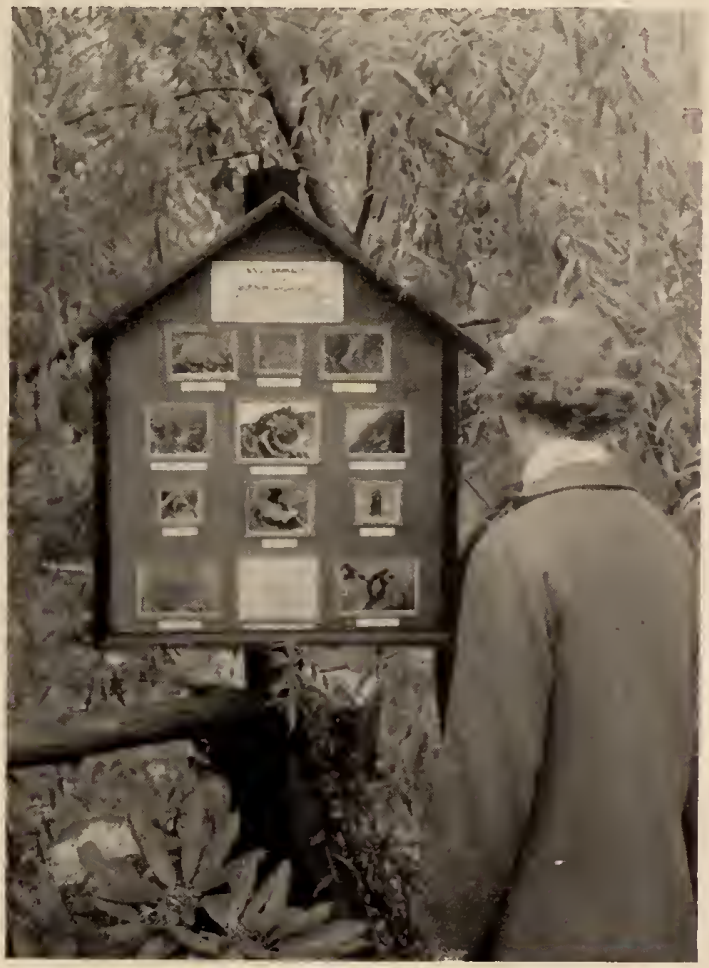

(Photograph by Thane Bierwert)

Large Animal Chart

An outdoor label of this type contains a great deal of information. Placed near the animal cages, it has been carefully read by many visitors. 


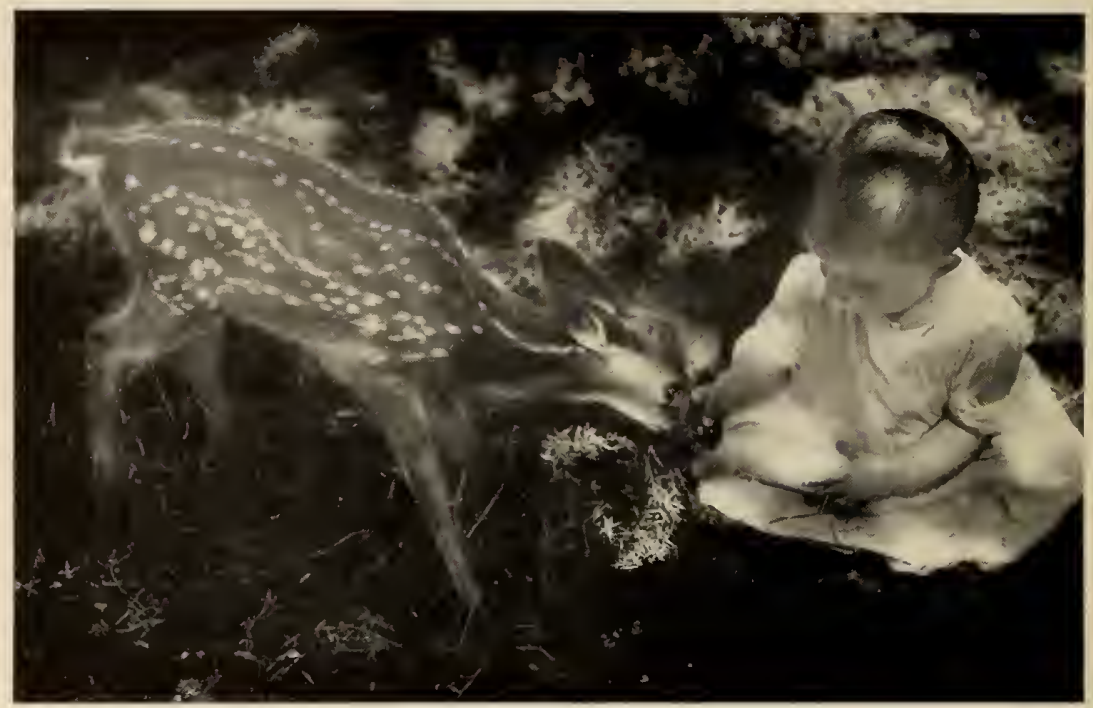

FEeding Time

A Dear feeds a deer unwittingly.

bers are usually present to invite and answer questions, to suggest reading matter, and to direct and assist the visitor in any way possible. Hundreds of talks (not lectures) are given to groups large and small. Museum visitors arrive at all hours, especially in summer. Our buildings are frequently open from eight in the morning until half past nine at night.

The Trailside Historical Museum is the largest building upon our Trailside area. Within its boulder-lined walls we are enTrailside deavoring to present a fairly complete picture of Historical Colonial and Indian activity in our local region. and

Indian

Museum Although the museum stands upon the site of Fort Clinton, we have taken pains not to over-emphasize the Revolutionary War. We are equally interested in the early industrial and home-making activities of the Highlands,--subjects, by the way, that have been woefully neglected.

Our ideal is to depict, by means of maps, old prints and general historical collections, the story of what has happened to the landscape of the Hudson Highlands from 1609 to the present time. This representation includes stories of early mining, 
lumbering, charcoal burning, and related human occupations. It would account, among other things, for the disappearance of the wild life population and the original forests prior to the formation of the Park.

In connection with the local battle of the Revolution, we intend to exhibit structural details of the fortifications by means of relief models and an excellent collection of old plans and prints. Materials such as cannon balls and bullets, actually excavated nearby, are shown in glass cases. The battle, fought so long ago, was decidedly a picturesque one. Nevertheless we wish to inform visitors of the fact that a greater interest lies in the "three hundred year story" than in the sanguinary encounter that took place on one afternoon.

A section of this museum is devoted to local Indian exhibits. Some fine specimens have been excavated and otherwise recovered by our staff. A splendid, detailed model of an Algonquin Indian village provides the center of interest here. In the cases and on the walls, implements are not merely displayed and labeled, but are presented with supplementary illustrative materials,-charts, diagrams, and drawings. In addition, vari-

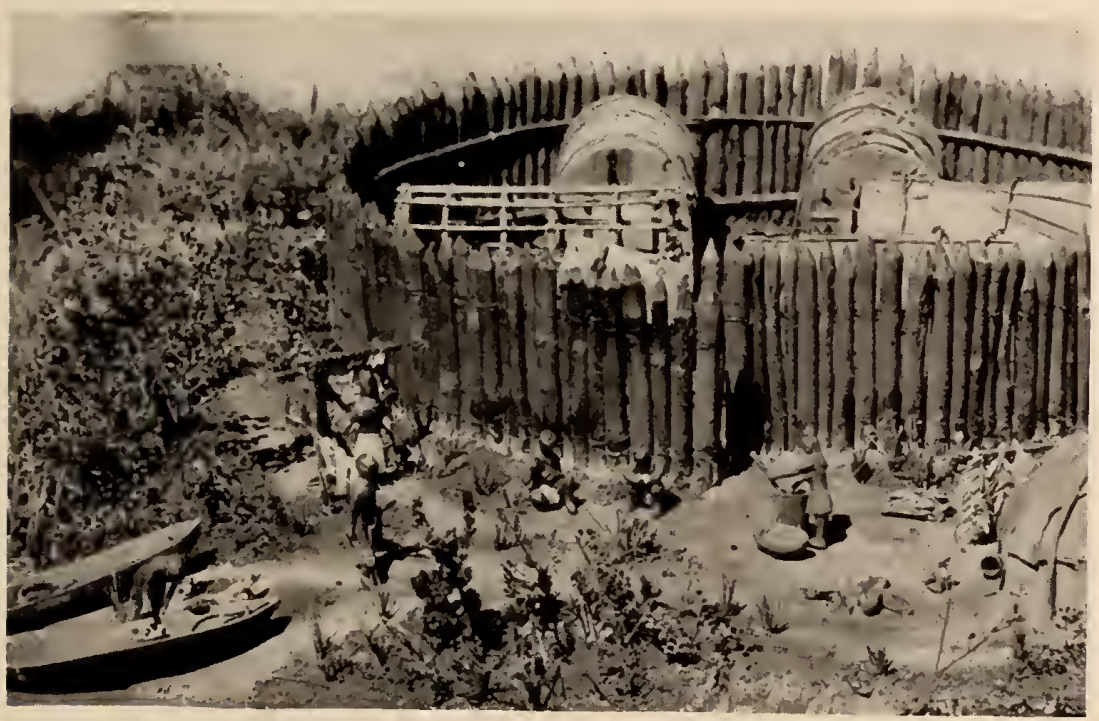

Model OF AN INdian Village

Models tell a vivid story, and, accompanied by explanations, prove of instructive value to school children and adults. 


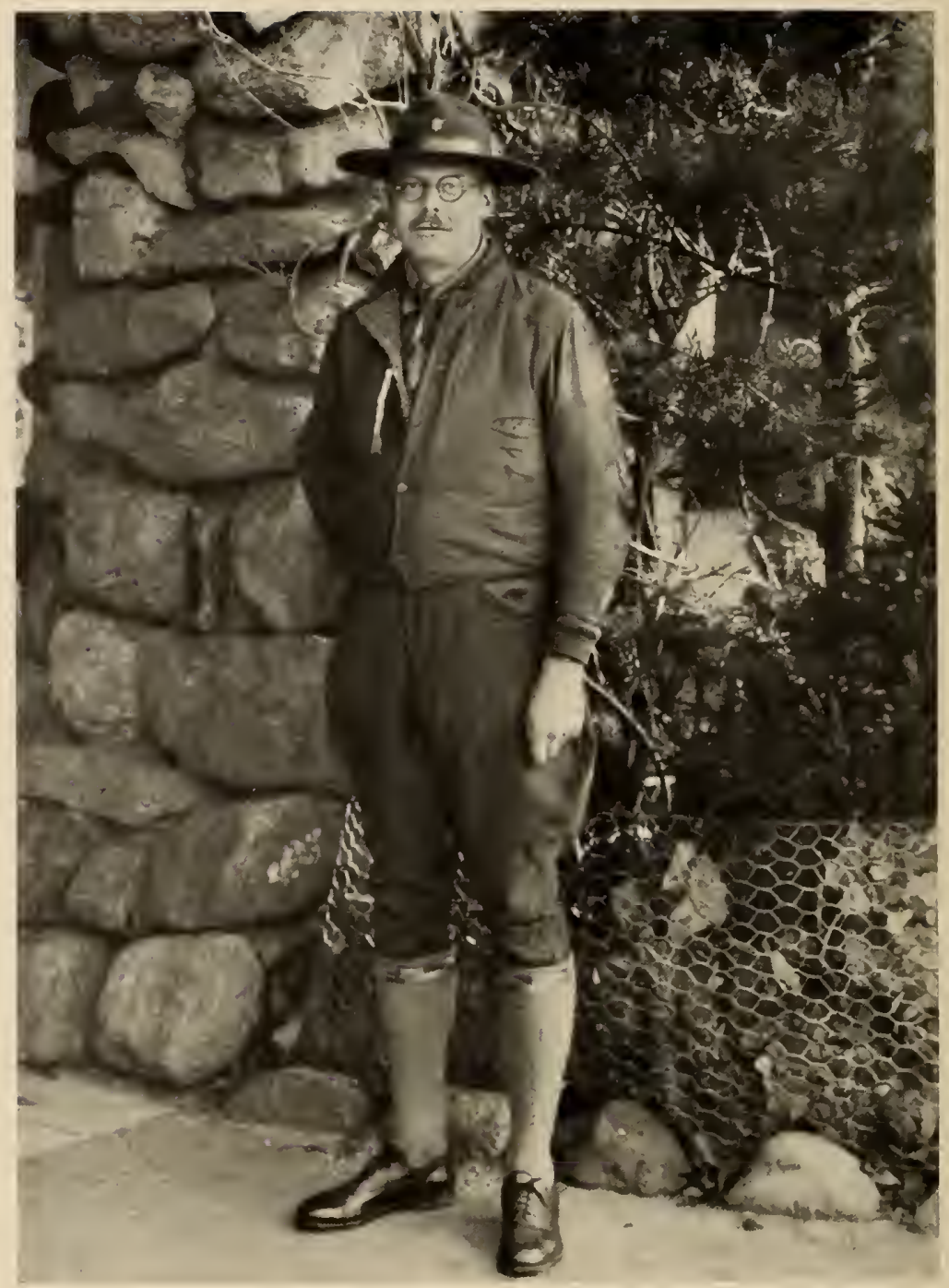

Mr. Benjamin Talbot Babbitt Hyde

"Uncle Bennie" was a pioneer in nature work in the Palisades Interstate Park. The Hyde Memorial Library has been dedicated to his memory. "Uncle Bennie" was a guide and councillor to thousands of young people. He was a modest, unassuming leader who possessed a seeing eye and an understanding heart. His death, in 1932, was a great blow to the cause of nature education. 
ous objects such as scrapers, arrow points, celts, and other items have been mounted in wood to show their position and appearance under actual "working conditions." Displays are changed frequently. Expositional, rather than exhibitional, methods are followed.

The Hyde Library, designed as a memorial to "Uncle Bennie" Hyde, is housed in the Trailside Historical Museum. Some Uncle five thousand volumes and six thousand separates and Uncle pamphlets are now upon the shelves. This is a referBennie's ence library, available to all who visit us. The subLibrary jects represented in the growing collection are carefully chosen items of natural history, human history, and Indian lore. A cross reference filing system is a valuable asset in this library. A great deal has been said about "studying nature more and books less." In some respects we are in hearty accord with this thought. Nevertheless, books, properly used, become tools necessary to one who would "study nature more."

It is essential that our staff be provided with books too. Therefore we have established small libraries in each Trailside

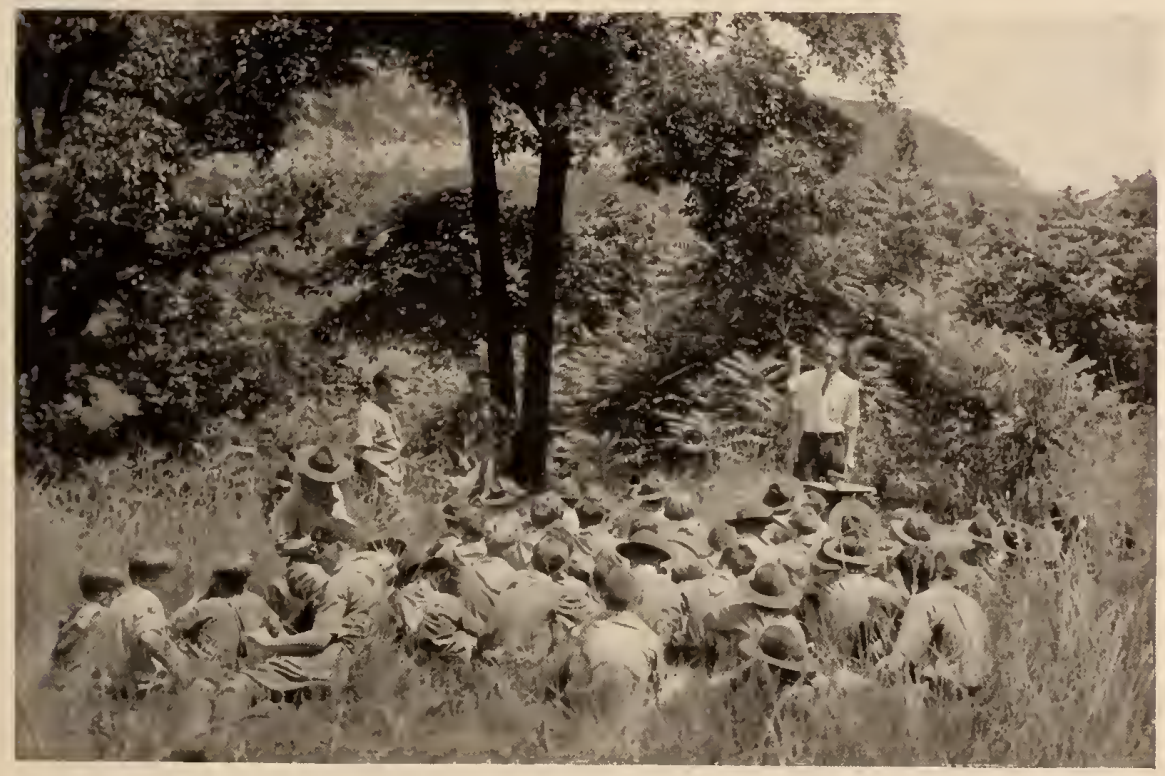

A Talk ON Historical Point 
Museum unit. All books, wherever they may be, are available to anyone who asks to see them. Our staff members are quick to suggest titles, locate page references, and to aid in any reasonable way in making books useful.

Those who visit our trails and for whom our work is carried on come from all walks of life. They include many nationaliVisitors ties, are of all ages, and arrive from every State in and

Attendance the Union. Visitors from thirty-five foreign countries have been recorded in eight years. Attend. ance figures for the first eight years are as follows:

\begin{tabular}{|c|c|c|c|c|c|c|}
\hline 1927 & 23,000 & 1930 & 一 & 200,000 & 1933 & - \\
\hline 28 & 53,000 & 1931 & & 283,000 & 1934 & - \\
\hline 729 & 130,000 & 1932 & 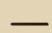 & 300,000 & & \\
\hline
\end{tabular}

These figures are based upon a careful estimate of trail and museum visitors within the fifty-seven acres. Actual counts were frequently made, indoors and out, and the results, compared with general park attendance, were used as a basis of exceedingly conservative computation. For a time we employed a signature book in the Trailside Museum. This was highly unsatisfactory as an efficient check upon attendance. Only one person in fifteen would sign, and many trail walkers did not visit the museums at any time during their stay within the Nature Trail area.

The vast majority of our guests come from the many Hudson River boats. Persons arriving by bus and private automobiles constitute approximately one fourth of the total. Those who come by train are the smallest group of all. Each year our attendance reaches the maximum from June fifteenth to September fifteenth.

Through long and painstaking observation, we have come to the conclusion that forty per cent of those who use our trails Percentages exhibit slight interest in our work. Their primary of

Interest object in coming to Bear Mountain is to enjoy themselves or to secure recreation. They "have eyes but see not." They are the ones who challenge us most of all. Another forty per cent are concerned to the extent of reading perhaps twenty labels in every hundred. Eighteen per cent are keenly interested and remain for many hours 
examining the majority of displays and asking innumerable questions. Typical comments heard from this group include:

"My! I'll have to spend a week here!" or

"You'd have to get up early in the morning to see everything here!" or

"I could spend a day in this building alone!"

One and one-half per cent of our visitors stay and stay, taking full advantage of our facilities and generally repaying us again and again by evidences of their appreciation. (Note: One and one-half per cent of the 400,000 visitors, in 1935 , is 6,000 persons.) The remaining one-half per cent (2,000 persons) returns frequently, month after month, year after year. Many of their faces and names have become familiar to us. They volunteer their services, seek paid positions, carry on a correspondence, sit in our offices, bring in specimens and act as guides.

Grade and high schools, private schools, normal schools, and universities and colleges, within a radius of one hundred miles of Bear Mountain, send many special groups to our trails. Garden clubs from far and wide and numerous other organiza-

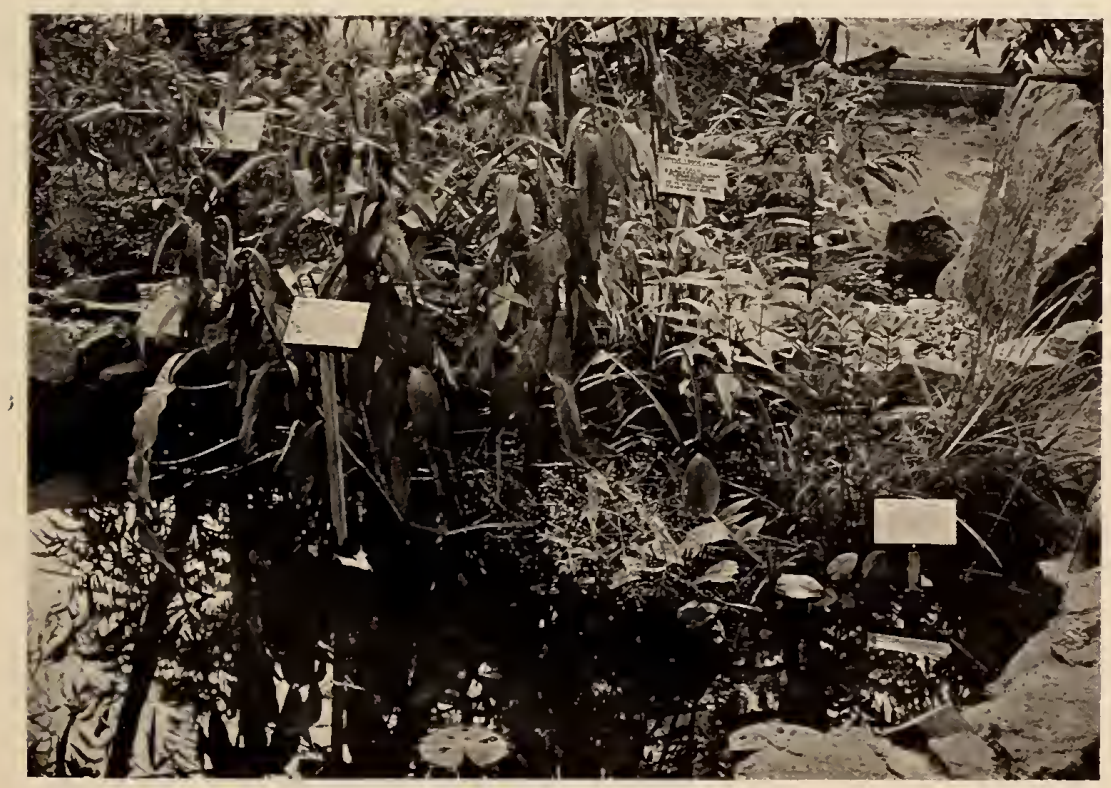

BOTANY POOL CORNER

Pulpit labels were needed to identify and describe some twenty species of water plants in the botany pool. 


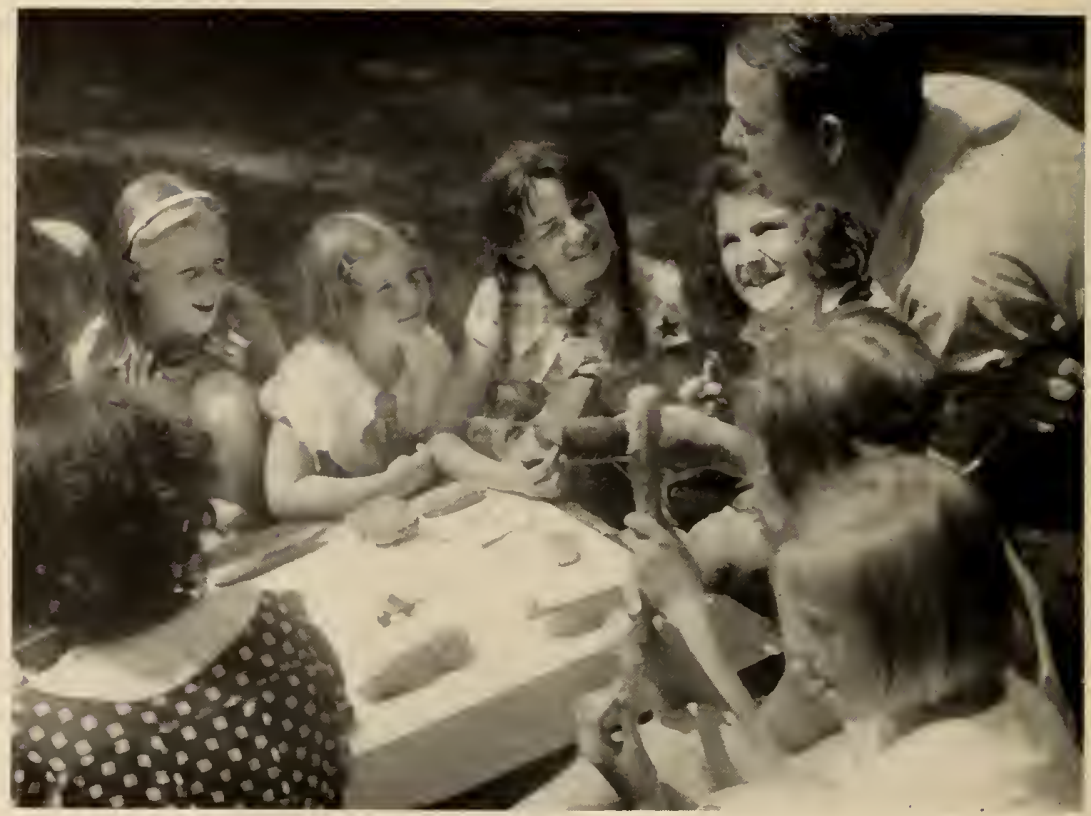

The Archaeologist Explains

Small models of Indian stone axes, knives, and other implements show clearly the way in which they are mounted, giving added interest to the artifacts on exhibit.

tions, including camps, hiking clubs, naturalists' clubs, Boy and Girl Scouts, orphans' homes, and many more come to us throughout the year. A number of these groups make annual pilgrimages on successive years. Hundreds of persons visit the museum in search of information regarding the identification of objects and the maintenance of personal and institutional collections.

Countless individuals from many states arrive especially to obtain knowledge concerning the building of Nature Trails and Trailside Museums. We have aided directly in the establishment of numerous similar institutions in the United States, in addition to several in Central and South America, in Europe, and one each in China, Japan, and Australia. We have been surprised on several occasions to wander over nature trails in different sections of the country and to discover labels with our wording upon them. In one instance we found several of the 
actual labels themselves! From all these and many other observations we realize that the out-of-door museum and nature trail movement has grown and is growing constantly. People are indeed "going back to nature." More than this we could not desire.

In the fall of 1934 it seemed that all of our effort at Bear Mountain was to cease through lack of funds. The "Trailside The "Bill" Museum Account" in the American Museum of Natural "Bill fact that our work had ever been carried on with the absolute minimum of expense. This was a discouraging time. It seemed only proper that an appeal should be made to the State inasmuch as our institution was operated in a State Park for State Park visitors. As a consequence, it was decided to formulate a Bill providing for the maintenance of the Trails for the approval of New York State legislators. T'his Bill was introduced by Assemblyman Lee B. Mailler and Senator Thomas C. Desmond, both of Orange County. It passed the Assembly and Senate promptly. Governor Herbert H. Lehman signed it on May 15, 1935. Had it failed, our work would have terminated on July 1, 1935 . The Bill provided for an appropriation to insure maintenance for one year. The staunch support of the American Museum of Natural History and the Commissioners of the Palisades Interstate Park was responsible for the introduction and passage of the Bill, and also made possible our continued operation under their joint sponsorship.

Although it is impossible to give thanks to all who aided us in connection with the success of the Bill in Albany, we must Supporters not fail to call attention to the fact that the imindividuals and organizations was of vital assistance in informing State officials of our needs. This hearty support was one of the most gratifying instances of friendship for our project that has come to us during the years since our Trailside work commenced. We have never witnessed widespread voluntary effort of similar intensity in the advocacy of any legislative matter concerned with out-of-door education elsewhere in the country.

Persons and groups from every State wrote and telegraphed the Governor in our behalf. So great was the avalanche of letters to the State Capitol that we have never been able to secure 


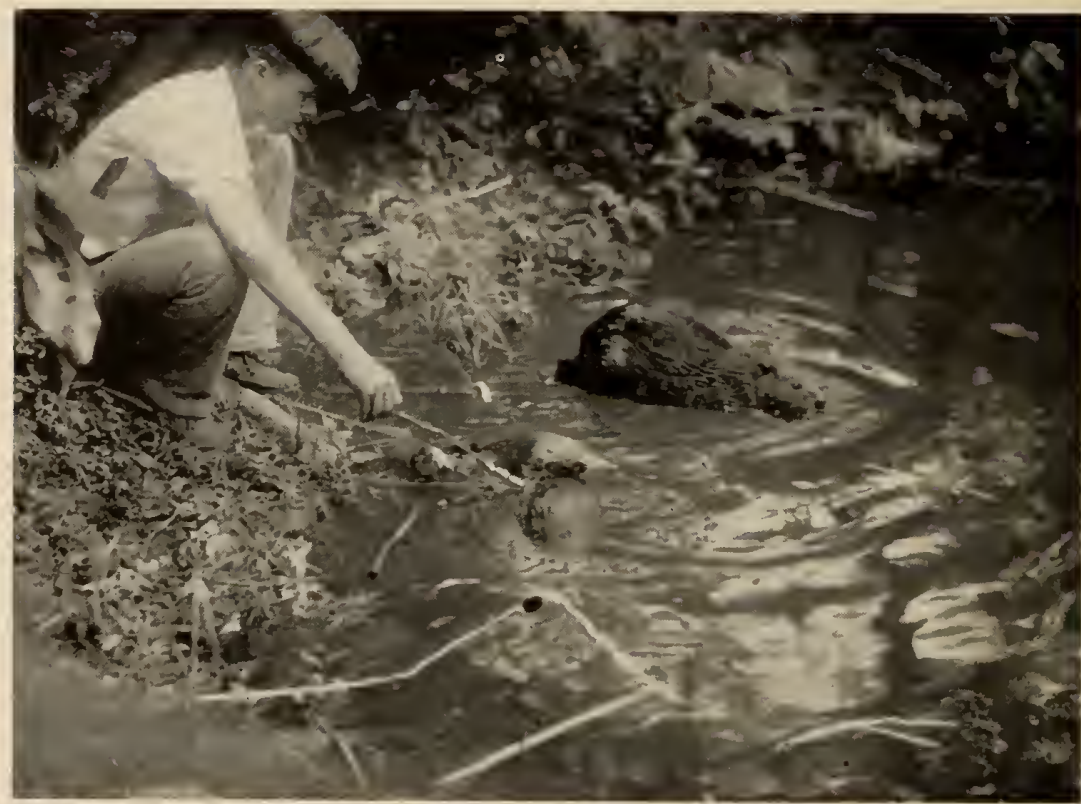

Beaver In Trailside Museum Beaver Pond

A mother beaver and two kittens were released in the enclosed pond in front of the Trailside Museum. The kittens were very tame, and the mother soon became so. Here they are feeding on green twigs offered by one of the museum staff.

the names of all individuals and organizations writing in our support. Freely printed newspaper publicity stimulated interest in our cause. Practically everything possible was done to insure against our having to lock the Trailside doors, remove the Nature Trail labels, and write finis to eight energetic years!

\section{Part Two \\ TWO MORE YEARS \\ $1935-1936$}

The building of an out-of-door natural history institution ultimately becomes a problem of studying Nature, not less, but Presen. Man more. The year 1936 marked our tenth annual tation opportunity to carry on the combined study. We have learned to appreciate the fact that in $\mathrm{Man}$, as in $\mathrm{Na}$ ture, nothing is insignificant. We have labored unceasingly to 
interpret both the minute and spectacular phases of local natural life to the end that all of our visitors, regardless of age, and social, cultural or educational background, could grasp the essentials of facts related. Our expositional methods of presenting subject material have included the kindergarten with the university, the direct with the indirect, and the circus with the opera. An informal and stimulating approach to educational objectives need not necessarily lack dignity wherein Nature is permitted to tell her own story.

Formality is shed like a cloak when one enters the forest. Especially is this true with persons to whom practically all phases of Nature have been a closed book and who avail themselves of freely offered opportunities to secure answers to questions pertaining to natural objects on every hand. We frequently hear the following:

"Why didn't I learn in school that it was safe to walk anywhere in these woods?"

"How little we know about the world we live in, after all."

"This is certainly one way to really see what you're looking at!"

These expressions of awakened interest are not as trite as they might seem at first glance. They are often indicative of fundamental "discoveries" on the part of park recreation seekers who suddenly find that there is more to the landscape than the outline of mountains.

On July first, 1935, our endeavors went forward with financial support from the State of New York. One year later our New funds came directly from the Palisades Interstate Devel- Park Commission, with the American Museum of opments Natural History continuing to act as joint sponsor and advisor.

For the past two years we have been enabled to carry on trail and museum operation continuously, summer and winter. Pre. viously the Nature Trails and Museums were maintained only during the spring and summer months. As a consequence of this doubled working period there are many new developments, both indoors and out. In addition to serving the large proportion of New York City visitors, we now direct our attention to local communities, schools, and clubs in Orange and Rockland Counties, New York. Winter operation and the need for additional "snow time" exhibits also provide new and interesting problems. 
Another feature of year-around operation has been the appointment of a permanent staff. In 1936 the following assistants were engaged:

ANTHONY L. RoOS

KENNETH M. LEWIS.

RICHARD J. KOKE.

JAMES D. BURGGRAF.

ANDREW T. MCKEE..

STEWART H. FISHER

WARREN C. WILSON.

RiChaRD H. MANVILLE

ERnEST L. CroWE...

Miss Nina Thomas.

General Assistant and Trail Chief Zoologist

Historian

Archaeologist

Secretary

Assistant Zoologist

Horticulturist

Assistant Zoologist

Draughtsman

The first five staff members mentioned above are permanent employees. In addition, there were several other temporary employees, including twenty-eight young men from the $\mathrm{Na}$ tional Youth Administration, bringing our total number of aids to forty-two. All of the assistants performed yeoman service. The regular staff, several of whom have been employed for the past four years, worked on the average of ten hours each day throughout the summer, performing a multiplicity of tasks to further the interests of numerous projects.

Mr. Anthony L. Roos, in addition to his work upon the Nature Trails, is responsible for the new features in the Snake Animal

Area

Pit area, near the Trailside Geology Museum. Exhibits here include seven outdoor cages for small mammals, the opossum, skunk, weasels, chipmunk, whitefooted mice, gray fox, beaver, raccoon and woodchucks. Nothing could be farther from our Trailside ideals than to establish a zoo. This collection of "everyday animals" is exhibited to answer the question,_- "What mammals may I expect to see on my walks through the park?"

In addition to the representative living mammals shown in the open, there are complete collections of mammal study skins. Thirty-eight local species, while not on exhibit, are available to all who seek additional information.

Recent developments in botanical displays include a new Trailside Fernery. General visitors and students particularly Fernery have shown considerable interest in ferns. Several Trails in the past. However, no attempts were made to provide complete collections. Consequently, when the opportunity came, we located a new fernery near the Bear Mountain Bridge en- 
trance, where rock ledges, field conditions, and a moist area combined to furnish an excellent background for the work.

Mr. Warren C. Wilson was employed to develop the project. He has successfully collected and transplanted hundreds of ferns since the inception of the project in June, 1935. Fiftytwo species are now growing in the half-acre area. In addition, Mr. Wilson has vastly improved the section with other plantings, grading, and the removal of construction material discarded during the building of the Bear Mountain Bridge.

The transition from ferneries to Indian field work is some-

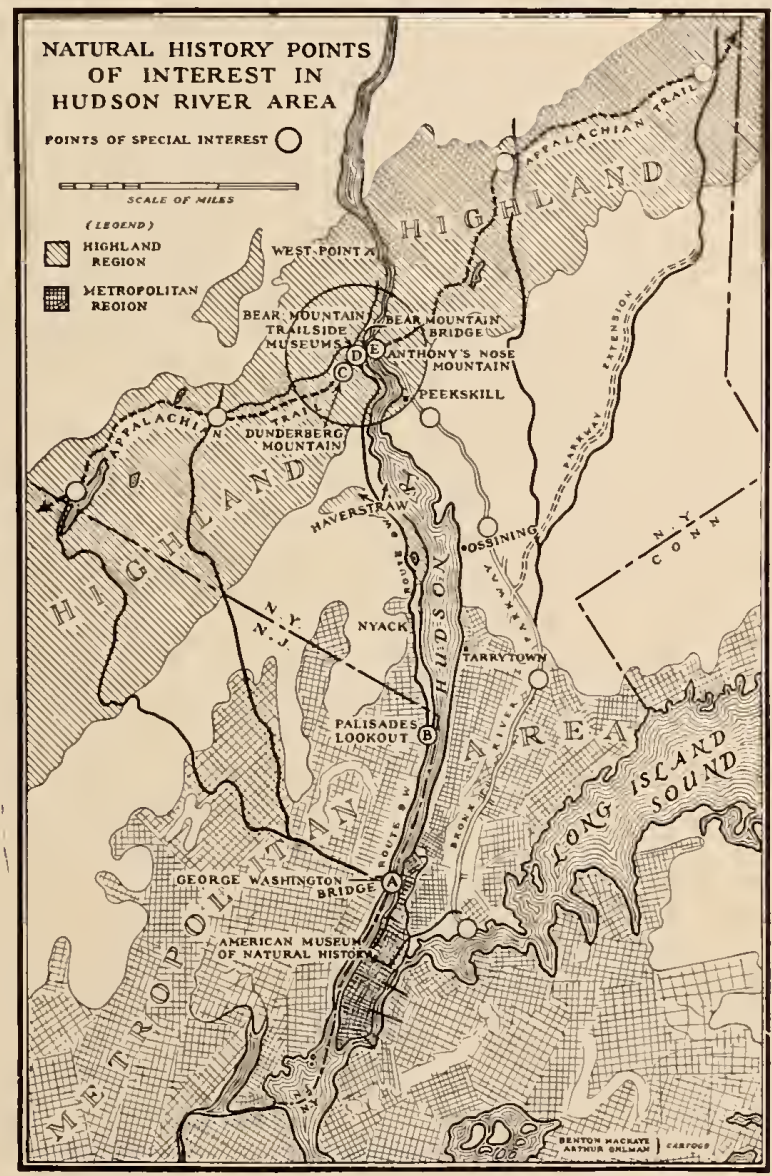

From the american Museum to Bear Mountain

The Trailside Area is located within the circle. 
what rapid. Nevertheless it is but a step from the botanical Archaeological

Field

Work display to the Indian and Historical Museum! In addition to telling stories of bygone local Indian life, by means of hundreds of specimens, miniature habitat models and pictures, we have also carried on extensive field work and research in the adjacent counties of Orange and Rockland.

Mr. James D. Burggraf, Trailside Archaeologist, visited and scientifically "worked" forty-two sites, recovering twenty-five hundred specimens, including arrowpoint, celts, hammerstones, knives, scrapers, drills, pottery, and other types of Algonquin and Iroquois artifacts and implements. Camp sites, rock shelters and village sites have been discovered and excavated. Many implements have been recovered from surface hunting and from the investigation of discarded "workshop" sites.

Mr. Richard J. Koke, Historian, in addition to his numerous museum duties, has carried on exhaustive research in conHistorical

Field

Work nection with the Colonial and Revolutionary History of the Hudson Highlands with special reference to immediately local military engagements. He has labored for more than a year in the work of excavating the interior site of the picturesque West Redoubt of Fort Clinton, and completed the task in October, 1936. With our Archaeologist as co-worker he sifted many tons of earth with painstaking care, to examine every shovelful.

Historical materials exhibited and recovered from the above site include seven hundred lead musket balls of various types, ranging in size from 54 to 69 calibers; two hundred and sixty grape shot of four sizes; ten cannon balls of six pounds each; bayonets, parts of muskets, regimental buttons, including the 63rd and 23rd British Regiments; fifty-seven British and American gun flints, and other traces of the occupation of and the battle at the Fort. Other materials exhibited in the Trailside Historical Museum include two hundred and forty objects received as gifts from fifty-five donors. Lack of space prevents the inclusion of the names of these patrons of the museum.

The Winter of 1935-36 was a rigorous one, to say the least. We received our first complete Trailside boreal baptism under 
Trailside the best of frigid auspices. Small, round, iron stoves, in

Winter in which fires had to be built each morning and with stovepipes projecting from windows, supplied the warmth to enable us to keep open the Zoology, Geology, and Craftshop exhibits daily. An open fireplace in the Trailside Historical Museum made possible the daily opening of this building, although it was impossible for the staff to work within its cold, rocky walls. All of us enjoyed the arctic experience very much indeed, even when we found it necessary to shovel our automobile parking space by hand after several two-foot snowfalls had buried it deeply.

In general, winter activities included maintenance of the four buildings mentioned above, field work in connection with wild life conservation, lectures in schools, and a number of other regular duties. For the first time, we were enabled to carry on a program of museum work with few interruptions during the sub-zero weather. In the warm months a large percentage of our working hours is devoted to people. This is as it should be. However, we welcomed the winter months, for they provided added opportunities to build exhibits that had been in demand for years.

Relief models, maps, frames, cases and other objects were manufactured by our staff for the Historical and Indian $\mathrm{Mu}$ seum. Five of us worked in the Craftshop throughout the winter, for, with the loss of the Temporary Emergency Relief Administration aid, we were without carpenters and handymen, with the result that all museum materials were manufactured by ourselves, with the occasional and much valued expert aid of the Bear Mountain Carpenter and Machine Shops. A new fluorescent exhibit of sizable and sturdy proportions and several other tactile devices were made for the Geology $\mathrm{Mu}$ seum. Tables, cases, shelves, cages, file boxes, bulletin boards, numerous picture and chart frames, label holders, and other items were made for the Zoology Museum. Nature Trail equipment manufactured during the winter included hundreds of labels for trail signs, and label posts. A large electric "bird finder" was made and presented to the National Association of Audubon Societies, and several similar devices were given to other organizations. Without the constant aid, both ma- 
terial and advisory, of the Park Construction Department, many of our projects would never have been attempted.

Through group and individual visits and lectures, 312 grammar schools, 165 high schools and 46 colleges and universities Contacts have been directly aided by the Trailside Museums Contacts during 1935-1936. In addition, we have corresponded with 32 other universities, 128 museums, and 42 libraries, bringing our total of educational institution contacts to seven hundred and twenty-five, over a two-year period. Also, we have lectured to and guided 28 garden clubs, 30 men's and women's clubs, and 48 youth organizations, including hiking clubs and Boy and Girl Scout Troops; State and National Park contacts by letter and visit numbered 112. Forty-eight state parks were visited by Trailside staff members in eighteen States. Various conventions were attended and papers were delivered at meetings, including those of the American Museums Association and the National Conference on State Parks. Direct assistance has been rendered to such conservation groups as the National Association of Audubon Societies, the Bureau of Biological Survey, and the Wildlife Technician Service of the National Parks. The total number of recreational organizations and educational institutions reached is 1,011. Sunday field trips were organized for the Orange County Biology Teachers. The annual fall gathering of the New York Biology Teachers' Association and many similar groups meet at the Nature Trails.

The total attendance from 1927 to 1934 was $1,719,000$. In 1935 there were 400,000 visitors, and in 1936, there were 420,000. Attendance The grand total for ten years is 2,539,000.

Millions seek our Highland region today where thousands came yesterday. America is becoming nature-minded as never The before. Various economic and social ills may very Future well lead an enlightened public to search for fundato turn to the fields, woods, and streams for surcease from troubles of many sorts. Whatever the reason, the fact is that the Trailside movement will grow in direct proportion to this open air exodus.

There is nothing artificial in the out-of-doors. The fundamentals of life and living seem, somehow, to descend upon one 
who enjoys a peaceful contemplation of Nature far from cities. Nature Trails add to the hiker's unhurried delight of the woodland scene by acquainting him with the diversity of interest in the world out-of-doors. There can be no better place to engage in natural history pursuits than where Nature has her home and being. Ten years of nature trailing have not been enough. Our work has barely commenced.

\section{BIBLIOGRAPHY}

Reports Published by the American Museum of Natural History BY WILLIAM H. CARR

"Signs Along the Trail," (1927, 29 pages, 20 illustrations). Second edition, 1930. Price, 10 cents.

Beginnings of the Nature Trails and Trailside Museum at Bear Mountain, New York. Adventures in labeling and building-Botanical, Zoological and Historical Trails.

"Blazing Nature's Trail," (1929, 21 pages, 16 illustrations). Second edition, 1933. Price, 15 cents.

How Nature Trails are built-how labels are written. Correlations of trails and museums.

"Trailside Conversations," (1930, 36 pages and 27 illustrations). Price, 20 cents.

Live animals and their traits-their care and food. A talk about snakes - the study table-building Trailside charts. (Reprinted in, "A State Park Anthology," National Conference on State Parks, Washington, D. C., 1930, pp. 149-161).

"Trailside Actions and Reactions," (1931, 32 pages, 27 illustrations). Price, 20 cents.

Reactions of visitors to trails and museums-Trailside Psychology-Campers and Nature Trails, animals without labels-building cages.

"Trailside Family," (1932, 34 pages, 27 illustrations and full page map). Price, 20 cents.

Trails and those who build them. Building a botany pool. Animal habit index.

"Trailside Interdependence," (1933, 22 pages, 10 illustrations). Price. 15 cents.

From Sun to Soil and Plant to Man-an exhibit of relationships-building the Acorn Trail, depression attendance out-of-doors-Nature Trails for the blind.

"Trailside Transformation," (1934, 22 pages, 12 illustrations). Price, 15 cents.

Accounts of new Trailside Units, including Geology, Botanical and Crafthouse buildings, memorial page and photograph dedicated to "Uncle Bennie" Hyde.

By Frank E. Lutz. "Nature Trails," (1926, 36 pages, 14 illustrations). Price, 10 cents.

The Nature Trail near Tuxedo, N. Y., in the Palisades Interstate Park, (Operated from 1925 to 1927 ).

Insects along the trail, scientific vs. common names, labels.

Accounts of Activities-Bear Mountain Nature Trails and Trailside Muscums By William H. Carr

"Nature Trails," Scouting Magazine; July-August, 1927, 3pp. 
"Trailing Nature," Natural History Magazine; May-June, 1929, Vol. XXIX, 7 illustrations, No. 3, pp. 312-318. Descriptions of the trails and museums and those who visit them.

"Blazing The Nature Trail In Camp," Scouting Magazine; May, 1930, Vol. XVIII, No. 5, 4 pp.

“The Museum In Camp," Scouting Magazine; June, 1930, Vol. XVIII, No. 6, $5 \mathrm{pp}$.

“Nature Trailing," American Childhood Magazine; April, 1929, Vol. XIV, No. 8, pp. 5-8.

"Animals On The Nature Trail," Natural History Magazine; July-August, 1931, Vol. XXXI, No. 4, 9 illustrations, pp. 434-442. Mammals and birds and their care.

"Telling The Beaver Story," Natural History Magazine; November-December, 1931, Vol. XXXI, No. 6, 13 illustrations, pp. 640-650. An experiment in caring for beaver at Trailside.

"Adventures With Trailside Insects," Natural History Magazine; MarchApril, 1932, Vol. XXXII, No. 2, 24 illustrations, pp. 195-206. Insects and human visitors.

“Display Cages For Living Insects," Natural History Magazine, 1932, Vol. XXXII, No. 3, 2 illustrations, p. 333.

"Trailside Crows and Others," Natural History Magazine, May-June, 1932, Vol. XXXII, No. 3, 13 illustrations, pp. 313-320. The Crow as a Trailside staff member.

"A Trailside Convert," Natural History Magazine, May-June, 1933, Vol. XXXIII, No. 3, 11 illustrations, pp. 278-286. A fisherman's Trailside visit and his reactions.

"Two Thousand Miles Along The Crest of The Atlantic Highlands," Natural History Magazine, July-August, 1933, Vol. XXXIII, No. 4, 21 illustrations and 3 maps, pp. 395-408. A proposed series of Trailside Museums and Nature Trails along the Appalachian Trail system.

"Peter Poses," Natural History Magazine, September-October, 1933, Vol. XXXIII, No. 5, 11 illustrations, pp. 545-552. Adventures with a tame flicker-A Trailside exhibit.

"Creative A pproach to Nature Lore, in Summer Camps," Child Development Institute, Teachers College, Columbia University, 1933, pp. 22-24,

"Trailside Fawns," Natural History Magazine, March-April, 1934, Vol. XXXIV, No. 2, 10 illustrations, pp. 151-160. Experiences with White Tail Deer fawns as pets and exhibits.

NotE: Address orders for Reports to the Librarian, The American Museum of Natural History, Central Park West at 79th Street, New York, N. Y. All payments must be made in advance, and 3 cents additional postage must be sent for each pamphlet.

Trailside Museum Bulletins Ready For Publication But liaking Funds FOR PRINTING.

NoTE: Each bulletin will include information on life histories, habits, capture, care and feeding, field observations, etc.

"The Amphibians of The Hudson Highlands," by William G. Hassler.

"The Reptiles of The Hudson Highlands," by William H. Carr and Kenneth M. Lewis.

“The Mammals of The Hudson Highlands," by William H. Carr.

"The Birds of The Hudson Highlands," (in preparation).

"The Tivin Forts of The Popolopen," by William H. Carr and Richard J. Koke; Story of Forts Clinton and Montgomery; (60 pages and 15 illustrations).

Note: Any contribution to the Trailside Museum publication fund would be very gratefully received. 


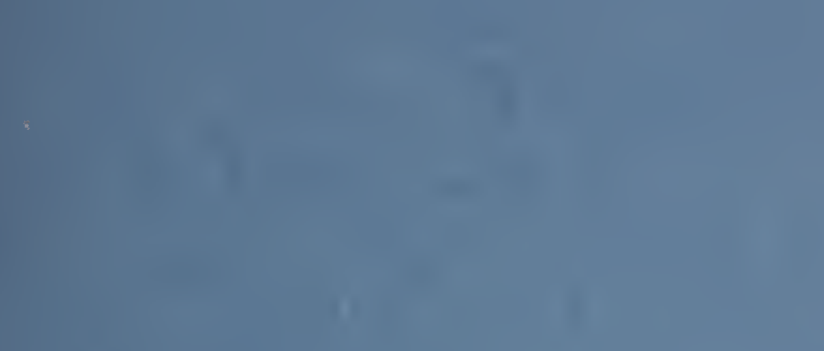

1.

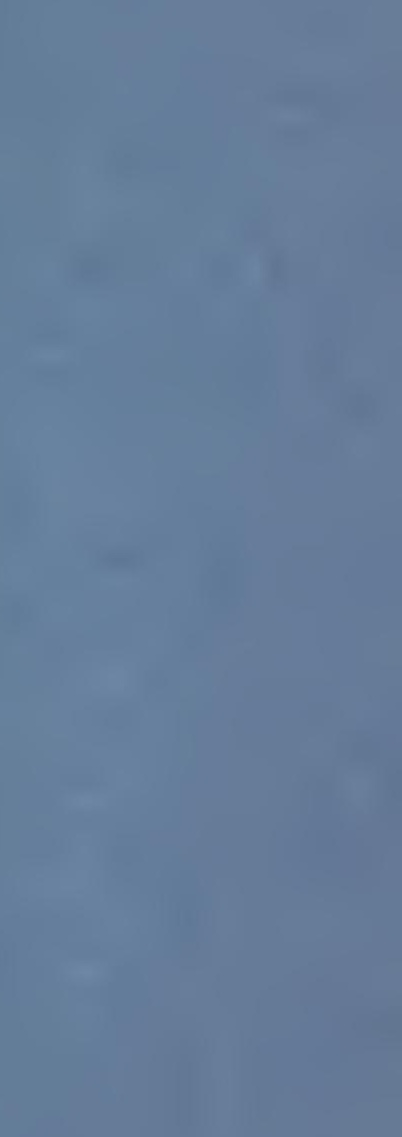

In

int

4

$4=$

4

$=$

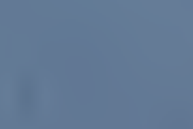

at

곤

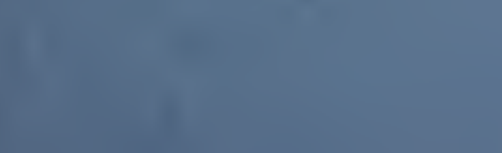



100191841 